\title{
Mechanism of Deactivation Processes of Excited Iron(III) Thiocyanato Complexes with Benacen-Type Ligands
}

\author{
Jozef Šima, Mário Izakovič, and Marián Žitňanský \\ Department of Inorganic Chemistry, Slovak Technical University, Radlinského 9, 81237 Bratislava, Slovakia
}

Received 10 November 2004; Revised 27 June 2005; Accepted 15 July 2005

The complexes $\left[\mathrm{Fe}(4-\mathrm{R}\right.$-benacen $\left.)\left(\mathrm{CH}_{3} \mathrm{OH}\right)(\mathrm{NCS})\right]$, where 4-R-benacen ${ }^{2-}$ are tetradentate open-chain $N$, $N^{\prime}$-ethylenebis $(4-\mathrm{R}-$ benzoylacetoneiminato) $\mathrm{N}_{2} \mathrm{O}_{2}$-ligands $\left(\mathrm{R}=\mathrm{H}, \mathrm{Cl}, \mathrm{Br}, \mathrm{OCH}_{3}\right)$, are redox stable in the dark in methanolic solutions. Irradiation of the complexes into intraligand and/or ligand-to-metal charge-transfer bands induces a series of photophysical and photochemical deactivation processes leading to $\mathrm{Fe}(\mathrm{II})$ and $\mathrm{CH}_{2} \mathrm{O}$ as final products in a $2: 1$ molar ratio. Formation of polystyrene containing bonded NCS group when irradiating the complexes in the presence of styrene monomer used as a radical scavenger indicates that the primary photoreduction of $\mathrm{Fe}(\mathrm{III})$ to $\mathrm{Fe}(\mathrm{II})$ is accompanied by the oxidation of $\mathrm{NCS}^{-}$ligand to ${ }^{*} \mathrm{NCS}$ radical. 4 -R-benacenligands behave as an innocent moiety virtually not participating in the photoinduced redox processes. The quantum yield of Fe(II) formation $\Phi_{\mathrm{Fe}(\mathrm{II})}$ decreases significantly with increased wavelength of the incident radiation, and is slightly influenced by the peripheral groups $\mathrm{R}$ of the 4-R-benacen-ligands.

Copyright (c) 2006 Jozef Šima et al. This is an open access article distributed under the Creative Commons Attribution License, which permits unrestricted use, distribution, and reproduction in any medium, provided the original work is properly cited.

\section{INTRODUCTION}

Contrary to halogeno and the majority of pseudohalogeno ligands, thiocyanato anion $\mathrm{NCS}^{-}$can coordinate to the central atom both through its nitrogen and sulphur terminal atoms. Up-to-now performed photochemical investigations of thiocyanato complexes have documented that they can undergo at least five types of radiation-induced reactions, namely,

(i) photosubstitution of $\mathrm{NCS}^{-}$anion, usually for a solvent molecule $[1,2]$, and photoanation substitution of a solvent molecule for an $\mathrm{NCS}^{-}$anion [3];

(ii) thiocyanato-isothiocyanato photoisomerization [4];

(iii) primary photooxidation of $\mathrm{NCS}^{-}$anion to ${ }^{\circ} \mathrm{NCS}$ radical associated by the central atom photoreduction followed by several fast reactions of the ${ }^{*} \mathrm{NCS}$ radical, for example, its reaction with $\mathrm{NCS}^{-}$anion forming the detectable anion-radical (NCS) ${ }_{2}{ }^{--}[1]$, dimerization yielding the molecule $(\mathrm{NCS})_{2}[5]$, redox reaction with a solvent molecule [6], initiation of polymerization by attacking a monomer molecule [7] and so forth;

(iv) photochemical decomposition of $\mathrm{NCS}^{-}$ligand through a sulphur atom loss [8] or formation of $\mathrm{NCS}^{-}$ ligand initiated by photodecomposition of $\mathrm{N}_{3}{ }^{-}$ligand and subsequent reaction of the nitrene intermediate with $\mathrm{CS}_{2}[9]$; (v) photochemical reaction not involving $\mathrm{NCS}^{-}$ligand, such as an electron ejection from the central atom (frequent process occurring at photoelectrochemical solar cells $[10,11])$ or photosubstitution of other ligands [12].

Along with potentially useful applications of thiocyanato complexes, "adverse" utilization of iron(III) thiocyanate as a camouflageing agent able to mask cocaine and facilitate thus its transport from Columbia to other countries [13] may be presented.

In this contribution, the results on photochemical properties of the complexes [ $\mathrm{Fe}(4-\mathrm{R}$-benacen $\left.)\left(\mathrm{CH}_{3} \mathrm{OH}\right)(\mathrm{NCS})\right]$ are presented. The structures of 4 - $\mathrm{R}$-benacen ${ }^{2-}$ where $\mathrm{R}=\mathrm{H}$, $\mathrm{Cl}, \mathrm{Br}, \mathrm{CH}_{3} \mathrm{O}$ (further on generally abbreviated as $\mathrm{N}_{2} \mathrm{O}_{2}$ ligands) and the central atom environment in the investigated complexes are depicted in Scheme ??

\section{EXPERIMENTAL}

\subsection{Reagents and solutions}

Methanol (Lachema, reagent grade) was dried before use by distillation from magnesium activated with iodine. The spin trapping agents 2,3,5,6-tetramethyl nitrosobenzene (nitrosodurene, ND) and 5,5-dimethyl-1-pyrroline-N-oxide (DMPO) were obtained from Aldrich. DMPO was freshly 


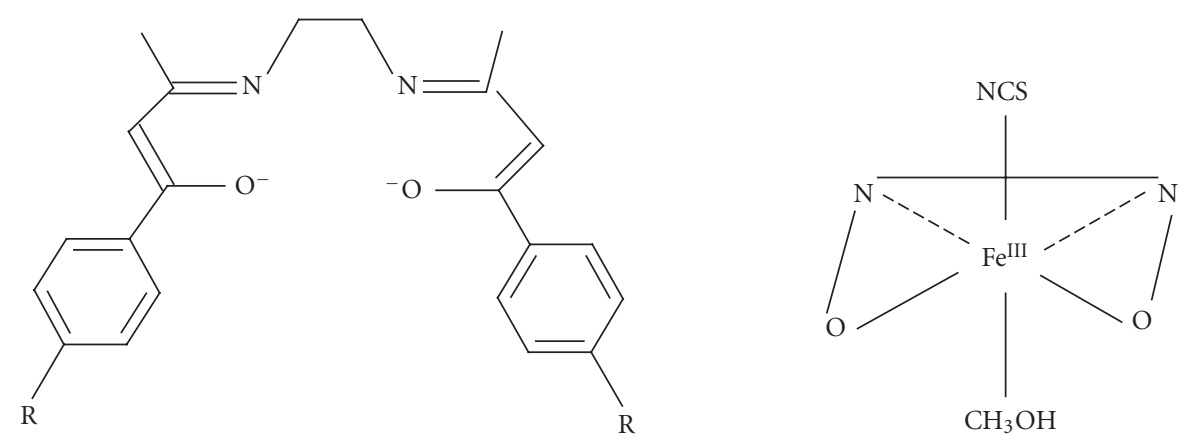

Scheme 1: Schematic representation of 4-R-benacen ${ }^{2-}$ ligands $\left(\mathrm{R}=\mathrm{H}, \mathrm{Cl}, \mathrm{Br}, \mathrm{CH}_{3} \mathrm{O}\right)$ and a mode of the ligands coordination to the central atom $\mathrm{Fe}(\mathrm{III})$.

redistilled before use and stored under argon in a freezer. Monomeric styrene was distilled before use and stored in a freezer. Potassium tris(oxalato)ferrate(III) (Oxford Organic Chemicals) and 1,10-phenanthroline (phen, Aldrich) were used directly without prior purification. The other chemicals were of analytical grade, purchased from Lachema, and used as received.

The Schiff bases $\mathrm{H}_{2}$ (benacen), $\mathrm{H}_{2}$ (4-Cl-benacen), $\mathrm{H}_{2}$ (4Br-benacen), and $\mathrm{H}_{2}$ (4- $\mathrm{CH}_{3} \mathrm{O}$-benacen) were available from our previous work $[14,15]$, their purity was checked by elemental analysis, melting point, ${ }^{13} \mathrm{C}-\mathrm{NMR}$ and ${ }^{1} \mathrm{H}-\mathrm{NMR}$ spectra.

Solutions of $\left[\mathrm{Fe}\left(\mathrm{N}_{2} \mathrm{O}_{2}\right)\left(\mathrm{CH}_{3} \mathrm{OH}\right)(\mathrm{NCS})\right]$ were prepared in situ diluting $40 \mathrm{~mL}$ of stock methanolic solution of $c\left\{\left[\mathrm{Fe}\left(\mathrm{N}_{2} \mathrm{O}_{2}\right)\left(\mathrm{CH}_{3} \mathrm{OH}\right)_{2}\right]\left(\mathrm{NO}_{3}\right)\right\}=3.00 \times 10^{-3} \mathrm{~mol} \cdot \mathrm{dm}^{-3}$ to $600 \mathrm{~mL}$ volume by dried methanol, adding $0.175 \mathrm{~g}$ of solid KNCS, and stirring at ambient temperature. Oxygen was removed from the photolyte solutions by purging with solventsaturated argon 30 minutes prior and during irradiation.

\subsection{Apparatus}

Solutions of investigated complexes were photolysed in a three-chamber thermostated $\left(20 \pm 1{ }^{\circ} \mathrm{C}\right)$ quartz photoreactor. A low-pressure germicidal lamp G8T5 or a high-pressure $150 \mathrm{~W}$ Hg-lamp (applied photophysics) were used as radiation sources. Radiation of the high-pressure lamp was monochromatized passing through solution filters [16].

Electronic absorption spectra were recorded on a Specord 200 spectrophotometer using 1.00 or $0.10 \mathrm{~cm}$ quartz cells. EPR spectra were measured using a computer controlled Bruker EMX instrument (operating at X-band, with $100-\mathrm{kHz}$ field modulation) equipped with a quartz flat cell optimized for the Bruker TM cylindrical EPR cavity. IR spectra of a solid polystyrene residue were scanned by KBr tablets technique on an FTIR spectrometer Nicolet Magna 750.

\subsection{Irradiation and product analysis}

The radiation intensities were periodically measured with ferrioxalate actinometry [17].
Progress of the photoredox processes was monitored by UV-VIS spectrophotometry as time evolution of $c\left(\mathrm{Fe}^{\mathrm{II}}\right)$ and $c\left(\mathrm{CH}_{2} \mathrm{O}\right)$. Iron(II) was determined in the form of $\left[\mathrm{Fe}(\text { phen })_{3}\right]^{2+}$, formaldehyde $\mathrm{CH}_{2} \mathrm{O}$ as 3,5-diacetyl-1,4dihydrolutidine. The total amount of photolysis was limited to less than $5 \%$ to avoid an inner filter effect. Details on the photolysis, analytical procedures, and experimental data processing are described elsewhere [14-16].

In EPR measurements, the prepared methanol solutions were carefully deoxygenated by an argon stream and irradiated directly in the cavity of EPR spectrometer by an HPA 400/30S lamp (Philips) at $\lambda \geq 300$. Spectrometer settings, a mode of simulations of the individual components of the EPR spectra, and the software used are given elsewhere [18].

Polystyrene formed within 30-minute irradiation of a solution prepared by adding $15 \mathrm{~mL}$ of styrene to $110 \mathrm{~mL}$ of $c\left[\mathrm{Fe}(\right.$ benacen $\left.)\left(\mathrm{CH}_{3} \mathrm{OH}\right)(\mathrm{NCS})\right]=2.00 \times 10^{-4} \mathrm{~mol} \cdot \mathrm{dm}^{-3}$ in argon atmosphere was separated as a solid residue using an MPW-type centrifuge (5500 rps) and washed twice with $5 \mathrm{~mL}$ of dry methanol.

\section{RESULTS AND DISCUSSION}

\subsection{Spectral properties and photoredox efficiency of complexes}

Single crystal X-ray diffraction investigations related to iron(III) complexes with thiocyanato ligands or benacentype ligands and solution studies show that

(i) $\mathrm{NCS}^{-}$anion is coordinated to the $\mathrm{Fe}(\mathrm{III})$ central atom through its nitrogen [19];

(ii) benacen-type ligands form the equatorial plane of the complexes and two monodentate ligands are bonded in the axial positions [19];

(iii) in the majority of its high-spin complexes, the central atom $\mathrm{Fe}(\mathrm{III})$ is hexacoordinated both in the solid state and solutions $[19,20]$.

Based on the literature data and our previous results obtained by a standard spectrophotometric titration [21], the composition of the complexes investigated within this work can be described as $\left[\mathrm{Fe}\left(\mathrm{N}_{2} \mathrm{O}_{2}\right)\left(\mathrm{CH}_{3} \mathrm{OH}\right)(\mathrm{NCS})\right]$. 


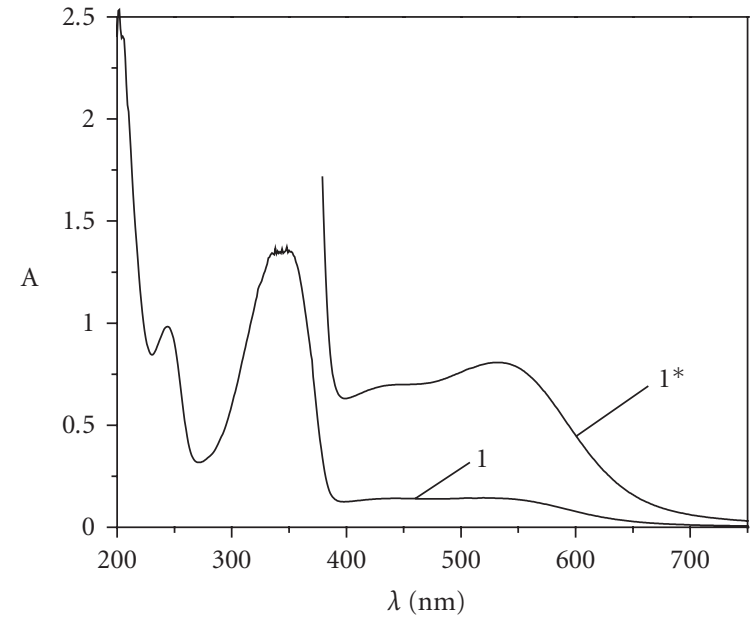

FIgURE 1: Electronic absorption spectrum of $2.0 \times 10^{-4} \mathrm{M}$ [Fe(benacen) $\left.\left(\mathrm{CH}_{3} \mathrm{OH}\right)(\mathrm{NCS})\right]\left(1,1^{*}\right)$ in methanol measured in $0.2 \mathrm{~cm}(1)$ and $1.0 \mathrm{~cm}\left(1^{*}\right)$ cells.

Typically, the electronic absorption spectra of the complexes $\left[\mathrm{Fe}\left(\mathrm{N}_{2} \mathrm{O}_{2}\right)\left(\mathrm{CH}_{3} \mathrm{OH}\right)(\mathrm{NCS})\right]$ consist of several broadbands and shoulders. As an example, absorption spectrum of $\left[\mathrm{Fe}(\right.$ benacen $\left.)\left(\mathrm{CH}_{3} \mathrm{OH}\right)(\mathrm{NCS})\right]$ is shown in Figure 1. The spectral data for all complexes are listed in Table 1.

Based on previously published data [14-16], bands in the visible region can be attributed to ligand-to-metal chargetransfer (LMCT) transitions $\mathrm{O} 2 \mathrm{p}$ or $\mathrm{N}(2 \mathrm{p}) \rightarrow \mathrm{Fe} 3 \mathrm{~d}$, the ultraviolet bands in the regions of $210-280 \mathrm{~nm}$ and 300 $360 \mathrm{~nm}$ to the intraligand transitions $\operatorname{IL}\left(\pi \rightarrow \pi^{*}\right)$ localized predominantly on the phenyl rings and on $\mathrm{C}=\mathrm{N}$ fragments of the $\mathrm{N}_{2} \mathrm{O}_{2}$-ligands, respectively. Due to their spin-forbidden nature, ligand-field (LF) bands were not observed in solution spectra.

Irradiation of methanolic solutions of the investigated complexes by UV or visible radiation gives rise to the photoreduction of $\mathrm{Fe}(\mathrm{III})$ to $\mathrm{Fe}(\mathrm{II})$. The integral quantum yields of $\mathrm{Fe}(\mathrm{II})$ formation $\Phi_{\mathrm{Fe}(\mathrm{II})}$ depend on the wavelength of the excitation radiation and on the peripheral groups $\mathrm{R}$ of the $\mathrm{N}_{2} \mathrm{O}_{2}$-ligands (Table 1). Blank experiments confirmed that the complexes $\left[\mathrm{Fe}\left(\mathrm{N}_{2} \mathrm{O}_{2}\right)\left(\mathrm{CH}_{3} \mathrm{OH}\right)(\mathrm{NCS})\right]$ do not undergo spontaneous redox changes in methanolic solutions in the dark.

Before starting discussion on the wavelength dependence of quantum yield of $\mathrm{Fe}$ (II) formation, it seems to be worth pointing out two specific features, namely,

(i) the absorption of a photon of $254 \mathrm{~nm}$ or $313 \mathrm{~nm}$ is associated with IL excitation localized on equatorial benacen-type ligand while it is an axial ligand undergoing the primary photoredox process;

(ii) inner complex physical deactivations are extremely fast for iron complexes and no radiation deactivation has been observed for such complexes up to now.

Taking these observations into account, the observed decrease in the quantum yield $\Phi_{\mathrm{Fe}(\mathrm{II})}$ with increasing incident radiation wavelength may be understood and summarized as a consequence of three main factors:

(1) very efficient internal conversion and/or intersystem crossing from energy higher IL to photoredox reactive LMCT states of the complexes;

(2) rate constants of the said photophysical partial deactivations are higher than that of rovibrational cooling with a consequence that LMCT states populated from IL states have a higher content of rovibrational energy than those populated directly by visible irradiation;

(3) the higher the difference between the rovibrational energy of a given LMCT state and the threshold energy of the primary photoproducts formation, the higher the probability of their separation (or, vice versa, the lower the probability of their recombination in the solvent cage), that is, the higher $\Phi_{\mathrm{Fe}(\mathrm{II})}$.

Since the investigated complexes provide no luminescence, continuous photolysis does not allow to distinguish between the photoredox reactivity of individual spinforbidden quartet and spin-allowed sextet LMCT states forming the manifold of states participating in redox deactivation processes.

Contrary to a theoretically justified and experimentally evidenced correlation of electrochemical reduction potentials for $\mathrm{Fe}(\mathrm{III})$ reduction and Hammett substituent constants of the groups R [22], a general unpredictability of quantum yields on such R-groups related parameters was explained in [23]. The main reason lies in the fact that electrochemical outer-sphere electron transfer occurs, in general, from the ground state of molecules and all usual parameters reflect molecular properties in this state. On the other hand, photochemical (frequently inner-sphere) electron transfer occurs from an excited state differing from the ground state in the structure, energy content, and electronic distribution.

\subsection{Radical intermediate identification}

To identify radicals formed in the irradiated solutions, EPR spin trapping and radical scavenging by a monomer were applied to $\left[\mathrm{Fe}\right.$ (benacen) $\left.\left(\mathrm{CH}_{3} \mathrm{OH}\right)(\mathrm{NCS})\right]$.

The EPR spectra of $\left[\mathrm{Fe}(\right.$ benacen $\left.)\left(\mathrm{CH}_{3} \mathrm{OH}\right)(\mathrm{NCS})\right]$ measured in methanol before photoexcitation revealed the formation of paramagnetic EPR signal characterized with the following hyperfine splittings: $\mathrm{a}_{\mathrm{N}}=1.363 \mathrm{mT}, \mathrm{a}_{\mathrm{H}}{ }^{\beta}=$ $0.775 \mathrm{mT}^{2} \mathrm{a}_{\mathrm{H}}^{\gamma}=0.16 \mathrm{mT}$; g-value $=2.0059$, which are attributed to ${ }^{-} \mathrm{DMPO}-\mathrm{OCH}_{3}$ adduct, in accordance with literature data [24]. This adduct is usually observed in systems of iron(III) complexes containing DMPO, a mechanism of its generation is proposed elsewhere [24], and it is not formed in a photochemical step. Continuous irradiation $(\lambda>300 \mathrm{~nm})$ of $\left[\mathrm{Fe}\right.$ (benacen) $\left.\left(\mathrm{CH}_{3} \mathrm{OH}\right)(\mathrm{NCS})\right]$ causes a decrease in the - $\mathrm{DMPO}-\mathrm{OCH}_{3}$ signal intensity without appearing any new EPR signal both at a short and prolonged irradiation. No EPR signal was observed using the ND spin trap as well.

Irradiation in the presence of monomeric styrene (soluble in methanol) gave rise to polystyrene (sparingly soluble in methanol) formation. In IR spectra of the polystyrene scanned after its isolation and purification, a sharp band 
TABLE 1: Electronic absorption spectral data (type of transition, absorption band maxima $\lambda_{\max }$ or shoulders $\lambda_{\text {sh }}$, and corresponding molar absorption coefficients, $\varepsilon$ ) for methanolic solutions of $2.00 \times 10^{-4} \mathrm{~mol} \mathrm{dm}{ }^{-3}\left[\mathrm{Fe}\left(\mathrm{N}_{2} \mathrm{O}_{2}\right)\left(\mathrm{CH}_{3} \mathrm{OH}\right)(\mathrm{NCS})\right]$, and quantum yields of Fe(II) formation $\Phi_{\mathrm{Fe}(\mathrm{II})}$ at the excitation wavelength $\lambda_{\mathrm{exc}}$.

\begin{tabular}{|c|c|c|c|c|c|c|c|}
\hline \multirow[t]{2}{*}{$\mathrm{R}$} & \multicolumn{3}{|c|}{$\lambda_{\max }$ or $\lambda_{\mathrm{sh}}, \mathrm{nm}\left(\varepsilon, \mathrm{mol}^{-1} \mathrm{dm}^{3} \mathrm{~cm}^{-1}\right)$} & \multicolumn{4}{|c|}{$\lambda_{\mathrm{exc}}, \mathrm{nm}$} \\
\hline & \multirow[t]{2}{*}{ IL(phenyl) } & \multirow[t]{2}{*}{$\mathrm{IL}(\mathrm{C}=\mathrm{N})$} & \multirow[t]{2}{*}{ LMCT } & 254 & 313 & 365 & 436 \\
\hline & & & & \multicolumn{4}{|c|}{$\Phi_{\mathrm{Fe}(\mathrm{II})} \times 10^{3}$} \\
\hline \multirow[t]{2}{*}{$\mathrm{H}$} & $240.7(23400)$ & $334.1(30900)$ & $440 \operatorname{sh}(700)$ & 36 & 12 & 0.36 & 0.20 \\
\hline & & $350 \operatorname{sh}(28000)$ & $543.2(900)$ & & & & \\
\hline \multirow[t]{2}{*}{$\mathrm{Cl}$} & $248.0(22900)$ & $318.8(25700)$ & $460 \operatorname{sh}(1500)$ & 68 & 9.1 & 1.3 & 1.1 \\
\hline & & $360 \operatorname{sh}(19500)$ & $541.9(1960)$ & & & & \\
\hline \multirow[t]{2}{*}{$\mathrm{Br}$} & $251.0(22400)$ & $319.1(26300)$ & $441 \mathrm{sh}(1900)$ & 46 & 8.0 & 4.4 & 0.91 \\
\hline & & $365 \operatorname{sh}(14800)$ & $537.6(2290)$ & & & & \\
\hline \multirow[t]{2}{*}{$\mathrm{CH}_{3} \mathrm{O}$} & $269.0(39800)$ & $335.7(42000)$ & $450 \operatorname{sh}(1800)$ & 48 & 7.5 & 2.7 & 1.9 \\
\hline & & $359 \operatorname{sh}(36400)$ & $558.9(2040)$ & & & & \\
\hline
\end{tabular}

at $1750 \mathrm{~cm}^{-1}$ was observed which is typical for covalently bonded SCN-group [25]. Such a results is generally taken as an indication of ${ }^{-N C S}$ radical formation and its involvement in radical initiation of polymerization.

\subsection{Final products determination}

A molar ratio of iron(II) and formaldehyde as the final products of photoredox processes $\mathrm{Fe}(\mathrm{II}): \mathrm{CH}_{2} \mathrm{O}$ approached a typical $2: 1$ value.

Introducing oxygen into the systems after switching off the irradiation led to a slow reappearance of the parent iron(III) complex spectra.

\subsection{Mechanism of photoinduced processes}

Based on the above spectra interpretation, radicals identification, molar ratio of the final products determination, and literature data $[26,27]$, processes occurring in the irradiated systems may be described (in the following equations, GS means the ground state) as follows. Composition of the complexes is written in a mode meeting the stoichiometry requirements, actual composition may vary within the processes due to kinetic lability of the complexes.

At UV-VIS irradiation of the investigated systems, spinallowed IL or LMCT excited sextet states of complexes (1) and (2) are populated:

$$
\begin{gathered}
\mathrm{GS}\left[\mathrm{Fe}^{\mathrm{III}}\left(\mathrm{N}_{2} \mathrm{O}_{2}\right)\left(\mathrm{CH}_{3} \mathrm{OH}\right)(\mathrm{NCS})\right] \\
\stackrel{h \nu(\mathrm{UV})}{\longrightarrow} \mathrm{IL}\left[\mathrm{Fe}^{\mathrm{III}}\left(\mathrm{N}_{2} \mathrm{O}_{2}\right)\left(\mathrm{CH}_{3} \mathrm{OH}\right)(\mathrm{NCS})\right] \\
\mathrm{GS}\left[\mathrm{Fe}^{\mathrm{III}}\left(\mathrm{N}_{2} \mathrm{O}_{2}\right)\left(\mathrm{CH}_{3} \mathrm{OH}\right)(\mathrm{NCS})\right] \\
\stackrel{h \nu(\mathrm{VIS})}{\longrightarrow} \text { LMCT }\left[\mathrm{Fe}^{\mathrm{III}}\left(\mathrm{N}_{2} \mathrm{O}_{2}\right)\left(\mathrm{CH}_{3} \mathrm{OH}\right)(\mathrm{NCS})\right]
\end{gathered}
$$

Of all the accessible excited states of the complexes, only LMCT sextet (populated directly by visible light absorption) and spin-forbidden LMCT quartet states (reached by intersystem crossing from energy higher IL states) possess the electron distribution suitable for an inner-sphere reduction of $\mathrm{Fe}$ (III) to $\mathrm{Fe}(\mathrm{II})$. The use of styrene and formation of polystyrene containing covalently bonded SCN-group indicates that within the primary photoredox step, the central atom reduction of $\mathrm{Fe}(\mathrm{III})$ to $\mathrm{Fe}(\mathrm{II})$ is associated with the ligand $\mathrm{NCS}^{-}$oxidation to its radical:

$$
\begin{gathered}
\operatorname{LMCT}\left[\mathrm{Fe}^{\mathrm{III}}\left(\mathrm{N}_{2} \mathrm{O}_{2}\right)\left(\mathrm{CH}_{3} \mathrm{OH}\right)(\mathrm{NCS})\right]+\mathrm{CH}_{3} \mathrm{OH} \\
\longrightarrow\left[\mathrm{Fe}^{\mathrm{II}}\left(\mathrm{N}_{2} \mathrm{O}_{2}\right)\left(\mathrm{CH}_{3} \mathrm{OH}\right)_{2}\right]+{ }^{\bullet} \mathrm{NCS}
\end{gathered}
$$

In spite of the absence of EPR evidence of the radical - $\mathrm{CH}_{2} \mathrm{OH}$, its formation by an intermolecular or intramolecular methanol oxidation cannot be a priori ruled out, contrary, given the formaldehyde formation, it must be taken into account.

The radical product(s) can participate in a number of subsequent processes (e.g., back electron-transfer reactions, radicals interconversions). As documented by the value $E^{o}\left({ }^{\bullet} \mathrm{CH}_{2} \mathrm{OH} / \mathrm{CH}_{2} \mathrm{O}\right)=-1.180 \mathrm{~V}$, the radical ${ }^{\bullet} \mathrm{CH}_{2} \mathrm{OH}$ is able to reduce ground state $\mathrm{Fe}$ (III) forming thus the final products $\mathrm{Fe}(\mathrm{II})$ and $\mathrm{CH}_{2} \mathrm{O}$ :

$$
\begin{aligned}
& {\left[\mathrm{Fe}^{\mathrm{III}}\left(\mathrm{N}_{2} \mathrm{O}_{2}\right)\left(\mathrm{CH}_{3} \mathrm{OH}\right)(\mathrm{NCS})\right]+{ }^{\bullet} \mathrm{CH}_{2} \mathrm{OH}} \\
& \quad \longrightarrow\left[\mathrm{Fe}^{\mathrm{II}}\left(\mathrm{N}_{2} \mathrm{O}_{2}\right)\left(\mathrm{CH}_{3} \mathrm{OH}\right)(\mathrm{NCS})\right]^{-}+\mathrm{H}^{+}+\mathrm{CH}_{2} \mathrm{O}
\end{aligned}
$$

The ratio of $c\left(\mathrm{Fe}^{\mathrm{II}}\right): c\left(\mathrm{CH}_{2} \mathrm{O}\right)=2: 1$ determined in the irradiated $\left[\mathrm{Fe}^{\mathrm{III}}\right.$ (benacen) $\left.\left(\mathrm{CH}_{3} \mathrm{OH}\right)(\mathrm{NCS})\right]$ indicates that the reduction of $\mathrm{Fe}$ (III) by ${ }^{\bullet} \mathrm{CH}_{2} \mathrm{OH}$ (4) is responsible for the above ratio.

\section{CONCLUSIONS}

(1) The paper deals with photoredox behaviour of the complexes $\left[\mathrm{Fe}(4-\mathrm{R}\right.$-benacen $\left.)\left(\mathrm{CH}_{3} \mathrm{OH}\right)(\mathrm{NCS})\right]$ where 4R-benacen $^{2-}$ are $N, N^{\prime}$-ethylenebis(4-R-benzoylacetoneiminato) ligands $\left(\mathrm{R}=\mathrm{H}, \mathrm{Cl}, \mathrm{Br}, \mathrm{OCH}_{3}\right)$. When irradiated in 
methanolic solutions into their IL or LMCT bands, the complexes undergo photoredox changes affording $\mathrm{Fe}(\mathrm{II})$ and formaldehyde $\mathrm{CH}_{2} \mathrm{O}$ as final products formed in a $2: 1$ molar ratio. The quantum yields of the formation of the final products depend both on the incident radiation wavelength and the tetradentate groups $\mathrm{R}$.

(2) Application of styrene as a radical scavenger evidences that ${ }^{-N C S}$ radicals are formed as intermediates; formation of $\mathrm{CH}_{2} \mathrm{O}$ indicates an involvement of ${ }^{\bullet} \mathrm{CH}_{2} \mathrm{OH}$ radicals in the photoredox processes.

(3) It is shown that the tetradentate ligands behave as an innocent part of the complexes. A mechanism of photophysical and photochemical deactivation steps is proposed.

\section{ACKNOWLEDGMENT}

The financial support of this work by a grant of the Slovak Grant Agency VEGA 1/925/02 is appreciated.

\section{REFERENCES}

[1] B. Mainusch, A. Karocki, D. M. Guldi, Z. Stasicka, and F. Wasgestian, "Charge transfer photochemistry of Reinecke's salt and of some of its analogues containing organic amines," Inorganica Chimica Acta, vol. 255, no. 1, pp. 87-93, 1997.

[2] H. J. Kuhn, S. E. Braslavsky, and R. Schmidt, "Organic and biomolecular chemistry division subcommittee on photochemistry," Pure and Applied Chemistry, vol. 76, no. 12, pp. 2105-2146, 2004.

[3] J. Sýkora and J. Šima, "Photochemistry of coordination compounds," Coordination Chemistry Reviews, vol. 107, pp. 1-212, 1990.

[4] G. L. Geoffroy and M. S. Wrighton, Organometallic Photochemistry, Academic Press, New York, NY, USA, 1979.

[5] T. Imamura, T. Jin, T. Suzuki, and M. Fujimoto, Chemistry Letters, p. 847, 1985.

[6] J. Šima, Polish Journal of Chemistry, vol. 66, p. 936, 1992.

[7] G. Ferraudi, "Photochemistry of high-spin iron(III) complexes of the macrocyclic ligands [15] pydieneN5 and [15]pyaneN5. An investigation of the charge-transfer processes," Inorganic Chemistry, vol. 19, no. 2, pp. 438-444, 1980.

[8] J. E. Moser, D. Noukakis, U. Bach, et al., "Comment on Measurement of ultrafast photoinduced electron transfer from chemically anchored Ru-dye molecules into empty electronic states in a colloidal anatase $\mathrm{TiO}_{2}$ film," The Journal of Physical Chemistry B, vol. 102, no. 18, pp. 3649-3650, 1998.

[9] H. Henning, K. Hofbauer, K. Handke, and R. Stich, Angewandte Chemie, vol. 109, p. 373, 1997.

[10] C. G. Garcia, A. S. Polo, and N. Y. Murakami Iha, "Fruit extracts and ruthenium polypyridinic dyes for sensitization of $\mathrm{TiO}_{2}$ in photoelectrochemical solar cells," Journal of Photochemistry and Photobiology A: Chemistry, vol. 160, no. 1-2, pp. 87-91, 2003.

[11] P. A. Anderson, F. R. Keene, T. J. Meyer, J. A. Moss, G. F. Strouse, and J. A. Treadway, "Manipulating the properties of MLCT excited states," Journal of the Chemical Society, Dalton Transactions, no. 20, pp. 3820-3831, 2002.

[12] E. Zinato, Concepts of Inorganic Photochemistry, edited by A. W. Adamson and P. D. Fleischauer, John Wiley \& Sons, New York, NY, USA, 1975.
[13] U. S. Drug Enforcement Administration, Drug Intelligence Brief, Black Cocain, 1999, http://www.dea.gov/pubs/intel/ 99016/99016.html.

[14] M. Izakovič, J. Šima, and V. Brezová, "Photochemical behaviour of iron(III) oxalato complexes with $N, N^{\prime}$-ethylenebis (benzoylacetoneiminato) Schiff base derivatives," Journal of Photochemistry and Photobiology A: Chemistry, vol. 167, no. 23, pp. 81-86, 2004.

[15] J. Šima and V. Brezová, "Photochemistry of iodo iron(III) complexes," Coordination Chemistry Reviews, vol. 229, no. 12, pp. 27-35, 2002.

[16] J. Sima, J. Mrázová, and A. Kotočová, “Photoredox properties of iron(III) fluoro complexes containing tetradentate openchain $\mathrm{N}_{2} \mathrm{O}_{2}$-ligands," Journal of the Chinese Chemical Society, vol. 46, no. 6, pp. 993-997, 1999.

[17] S. L. Murov, Handbook of Photochemistry, Marcel Dekker, New York, NY, USA, 1973.

[18] V. Brezová, P. Tarábek, D. Dvoranová, A. Staško, and S. Biskupič, "EPR study of photoinduced reduction of nitroso compounds in titanium dioxide suspensions," Journal of Photochemistry and Photobiology A: Chemistry, vol. 155, no. 1-3, pp. 179-198, 2003.

[19] M. Melník, I. Ondrejkovičová, V. Vančová, and C. E. Holloway, Reviews in Inorganic Chemistry, vol. 17, pp. 55-286, 1997.

[20] S. Funahashi and Y. Inada, "Solvation structures and solvent exchange reactions of metal ions in various coordinating solvents," Bulletin of the Chemical Society of Japan, vol. 75, no. 9, pp. 1901-1925, 2002.

[21] J. Šima, J. Mrázová, and A. Kotočová, "Preparation and photoinduced processes of ferric complexes containing fluoride and tetradentate salen-type ligands," Polish Journal of Chemistry, vol. 72, no. 9, pp. 2079-2086, 1998.

[22] A. Kotočová and J. Śima, Chemical Papers, vol. 48, p. 175, 1994.

[23] J. Šima, "Manifestation of peripheral group effects in photoredox reactions of complexes," Coordination Chemistry Reviews, vol. 159, pp. 195-204, 1997.

[24] F. Chen, Y. Xie, J. He, and J. Zhao, "Photo-Fenton degradation of dye in methanolic solution under both UV and visible irradiation," Journal of Photochemistry and Photobiology A: Chemistry, vol. 138, no. 2, pp. 139-146, 2001.

[25] J. Coates, "Interpretation of infrared spectra: a practical approach," in Encyclopedia of Analytical Chemistry, R. A. Meyers, Ed., pp. 10815-10837, John Wiley \& Sons, Chichester, UK, 2002.

[26] J. Šima, Comments on Inorganic Chemistry, vol. 13, pp. 277291, 1992.

[27] J. Šima, Roumanian Chemical Quarterly Reviews, vol. 7, pp. 159-171, 1999. 


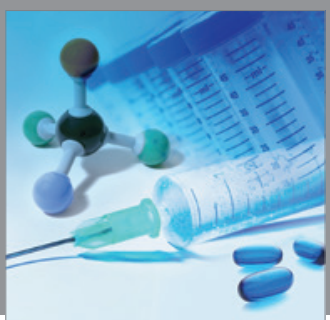

International Journal of

Medicinal Chemistry

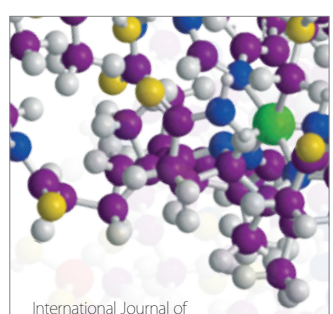

Carbohydrate Chemistry

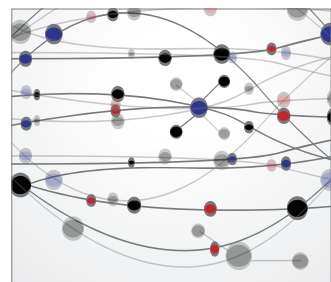

The Scientific World Journal
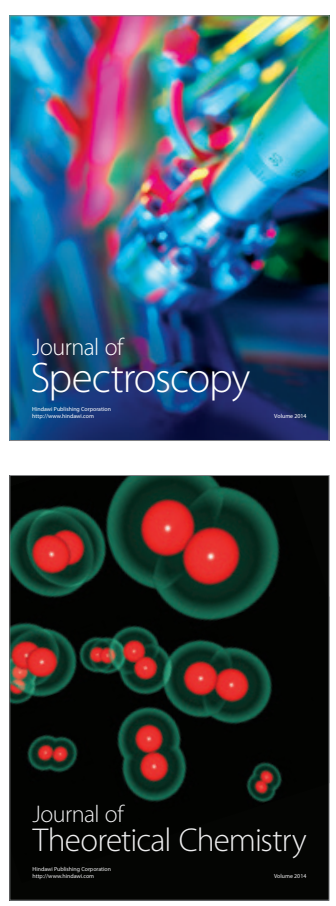
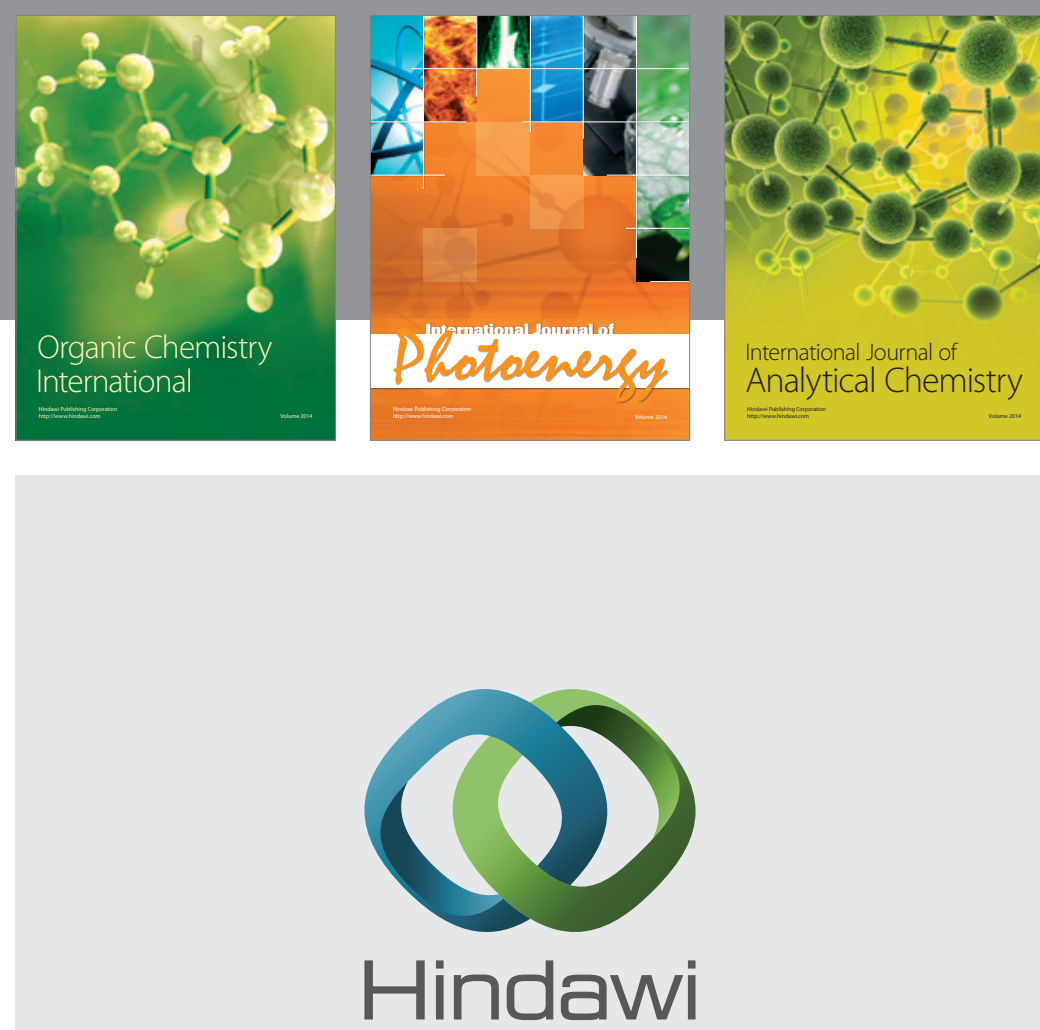

Submit your manuscripts at

http://www.hindawi.com
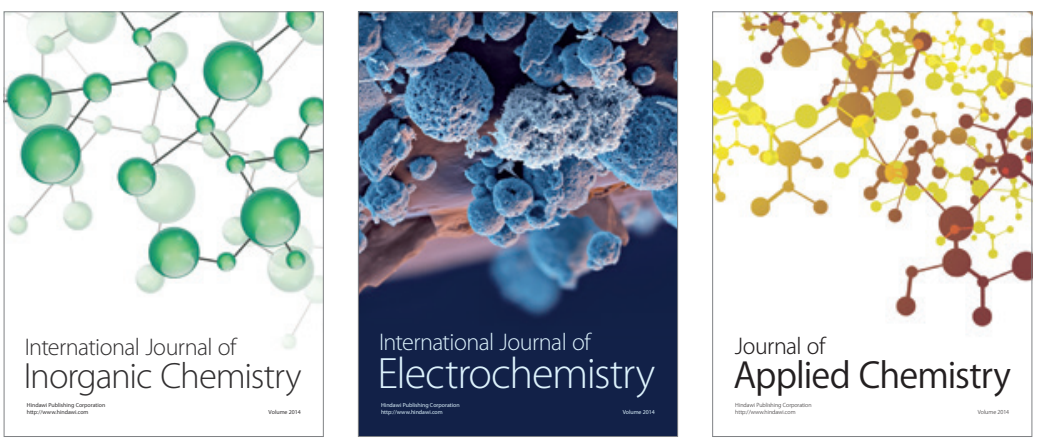

Journal of

Applied Chemistry
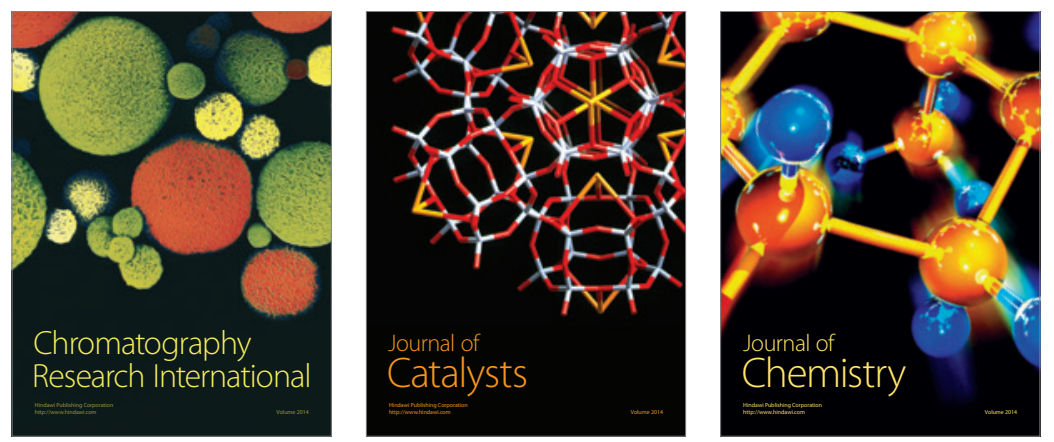
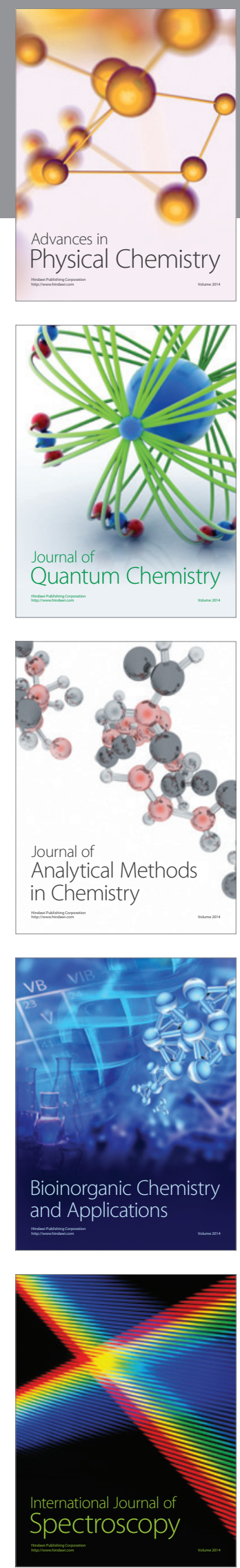